\title{
Korelasi Ekspresi Reseptor Vitamin D (VDR) dengan Derajat Diferensiasi dan Stadium Adenokarsinoma Kolorektal
}

\author{
Hermin Aminah, Yulie Erida, Herry Yulianti, Abdul Hadi Hassan \\ Departemen Patologi Anatomi Fakultas Kedokteran Universitas Padjadjaran \\ Rumah Sakit Dr. Hasan Sadikin Bandung
}

\begin{abstract}
Abstrak
Keganasan terbanyak ketiga di dunia pada organ kolorektal adalah karsinoma yang berasal dari lapisan epitel mukosa. Modalitas yang digunakan untuk terapi karsinoma kolorektal stadium lanjut selain operasi adalah kemoterapi dan saat ini dikembangkan terapi target sebagai alternatif terapi, yaitu metabolit aktif vitamin D, calcitriol. Calcitriol bekerja sinergis dengan agen kemoterapi yang aktivitasnya dimediasi oleh vitamin D reseptor (VDR). Penelitian ini bertujuan mengetahui korelasi imunoekspresi VDR dengan stadium dan derajat diferensiasi (grading) pada adenokarsinoma kolorektal. Menggunakan 35 blok parafin adenokarsinoma kolorektal yang diambil dari kolektomi, di Departemen Patologi Anatomi Rumah Sakit Dr. Hasan Sadikin Bandung periode 1 Januari 2009-30 Juni 2014, terbagi dalam 3 kelompok stadium (I, II, dan III) dan 3 kelompok derajat diferensiasi (well, moderately, dan poorly differentiated). Imunohistokimia dilakukan pada sampel untuk melihat ekspresi VDR pada massa tumor menggunakan antibodiprimer VDR. Data dianalisis menggunakan uji statistika korelasi Rank Spearman. Terdapat korelasi imunoekspresi VDR dengan stadium $(\mathrm{p}=0,045 ; \mathrm{R}=-0,341)$ dan derajat diferensiasi $(\mathrm{p}=0,000 ; \mathrm{R}=0,558)$. Pada penelitian ini VDR berperan dalam menentukan stadium dan derajat diferensiasi adenokarsinoma kolorektal. Hal ini dapat dijadikan pertimbangan dalam pemberian calcitriol sebagai bagian dari terapi target pada adenokarsinoma kolorektal dan acuan untuk penelitian selanjutnya dalam perkembangan terapi target. [MKB. 2016;48(2):123-8]
\end{abstract}

Kata kunci: Adenokarsinoma kolorektal, derajat diferensiasi, imunoekspresi VDR, stadium

\section{Correlation of Vitamin D Receptor (VDR) Expression with Differentiation Staging and Grading in Colorectal Adenocarcinoma}

\begin{abstract}
Colorectal carcinoma (CRC) is a malignancy from mucosal epithelium of the colon/rectum. The treatment modalities used for advance stage colorectal carcinoma therapy is chemotherapy, in addition to surgery. Targeted therapy is currently being developed as an alternative therapy. One of the agents used in this therapy is calcitriol. Calcitriol is an active metabolite of vitamin D. Calcitriol works synergistically with chemotherapeutic agents and its activity is mediated by the vitamin D receptor (VDR). VDR plays a role in the inhibition of tumor progression via induction of cellular differentiation and proliferation inhibition. In this study, imunoexpression of vitamin D receptor was examined in conjunction with the staging and degree of differentiation (grading) of colorectal adenocarcinoma. The study objects include 35 colorectal adenocarcinoma paraffin blocks created from colectomy which were collected at the Department of Patology Anatomic of Dr. Hasan Sadikin General Hospital Bandung from January 2009-June 2014. The blocks were divided into three groups of staging (I, II, and III) and three groups of grading: well, moderately, and poorly differentiated. Immunostaining was used to evaluate the VDR immunoexspression by histo-score. The data were tested using rank spearman test. There was a weak negative correlation between VDR imunoexpression and staging $(\mathrm{p}=0.045, \mathrm{R}=-0.341)$, and a moderate positive correlation between VDR imunoexpression and grading ( $p=0.000, R=0.558)$. It is concluded that a significant correlation of VDR imunoexpression with staging and grading of colorectal adenocarcinoma is found and this finding can be used as a reference for further studies in the development of targeted therapies. [MKB. 2016;48(2):123-8]
\end{abstract}

Key words: Adenocarcinoma colorectal, grading, staging, VDR imunoexpression

Korespondensi: Hermin Aminah Usman, dr., Sp.PA(K), Departemen Patologi Anatomi Fakultas Kedokteran Universitas Padjadjaran/Rumah Sakit Dr. Hasan Sadikin Bandung, Jalan Pasteur No. 38 Bandung, mobile 08112204910, e-mail hermin@ unpad.ac.id 


\section{Pendahuluan}

Adenokarsinoma kolorektal merupakan jenis keganasan yang utama yang terjadi pada epitel mukosa saluran cerna. ${ }^{1}$ Di negara maju maupun di negara berkembang seperti di Indonesia, jenis keganasan ini merupakan jenis kanker terbanyak ketiga dan masih menjadi masalah kesehatan nasional disebabkan oleh tingkat morbiditasnya yang tinggi. ${ }^{2}$ Insidensi keganasan ini semakin meningkat karena perubahan gaya hidup dan skrining kolonoskopi. Angka kejadian karsinoma kolorektal di Indonesia sekitar 19,1 pada pria dan 15,6 pada wanita per 100.000 penduduk. $^{3}$

Prognosis adenokarsinoma kolorektal itu ditentukan oleh stadium dan derajat diferensiasi tumor. ${ }^{4}$ Stadium tumor akan dipengaruhi secara langsung oleh kemampuan invasi sel-sel tumor, sedangkan tingkat diferensiasi sel tumor dipengaruhi oleh kemampuan sel dalam menjaga integritas matriks intraselulernya. ${ }^{5}$ Semakin tinggi stadium akan dikuti pula oleh semakin buruknya tingkat diferensiasi. ${ }^{4}$ Sebagian besar pasien adenokarsinoma kolorektal di Indonesia datang dalam stadium lanjut sehingga prognosis menjadi lebih buruk, keadaan ini memerlukan kemoterapi sebagai modalitas pendamping setelah dilakukannya reseksi tumor. Namun, sering kali kemoterapi tidak memberikan hasil yang memuaskan dan sering kali mengakibatkan efek samping yang buruk terhadap pasien yang intoleran. ${ }^{6}$

Salah satu terapi target untuk kanker yang sedang diteliti akhir-akhir ini adalah calcitriol. ${ }^{6}$ Terapi target merupakan terapi yang spesifik untuk menghambat faktor yang dianggap sebagai penyebab dalam patogenesis suatu kanrsinogenesis. Calcitriol merupakan metabolit vitamin D yang paling aktif. ${ }^{\text {Calcitriol pada }}$ eksperimen in vitro dan in vivo mengindikasikan bekerja secara sinergis dengan agen kemoterapi. Insufisiensi vitamin D memiliki peran dalam patogenesis kanker lambung, endometrium, paru-paru, esofagus, pankreas, ginjal, dan juga limfoma non-Hodgkin. ${ }^{8}$

Aktivitas calcitriol dimediasi oleh vitamin D receptor (VDR). ${ }^{9}$ Reseptor vitamin D merupakan anggota reseptor hormon steroid dan mengatur ekspresi gen dalam ligand-dependent manner.,10 Reseptor vitamin D berperan melalui jalur genomik dalam pengaturan pertumbuhan sel dan pada jalur nongenomik melalui penghambatan perkembangan dan progresivitas tumor berupa proses induksi diferensiasi seluler. Melalui ekspresi serta aktivitas enzim brushborders serta memperkuat formasi mikrovili dengan merangsang maturasi dari membran apikal mikrovili pada mukosa saluran cerna dan berperan pula dalam penghambatan proliferasi sel..$^{10}$ Penelitian menggunakan galur sel terbukti bahwa VDR berperan dalam diferensiasi sel dan menghambat proliferasi sel, hal ini menunjukkan bahwa vitamin D berperan dalam progresivitas tumor. ${ }^{11}$ Identifikasi VDR pada jaringan tumor dengan cara pemeriksaan imunohistokimia merupakan metode yang baik dan menjadi modalitas untuk menentukan terapi target. ${ }^{3}$

Penelitian ini bertujuan untuk mengetahui peranan VDR terhadap stadium dan derajat diferensiasi atau grading adenokarsinoma kolorektal, melalui penelitian tentang korelasi antara imunoekspresi VDR dengan stadium dan derajat diferensiasi pada adenokarsinoma kolorektal. Penelitian ini diharapkan mampu menjadi acuan untuk penelitian selanjutnya dalam perkembangan terapi target.

\section{Metode}

Penelitian ini dilakukan memakai rancangan observasi analitik potong lintang dengan bahan penelitian berupa blok parafin dari penderita adenokarsinoma kolorektal dilakukan tindakan operasi kolektomi. Terdapat 35 sampel yang terbagi atas stadium I, II, dan III berdasarkan sistem TNM. TNM mengklasifikasi ekstensi tumor primer ( $\mathrm{T}$ ), kelenjar getah bening regional $(\mathrm{N})$, dan metastasis jauh (M), serta stadium akan dinilai berdasarkan T, N, dan M. ${ }^{12}$ Sistem ini dibuat oleh American Joint Committee on Cancer (AJCC) dan International Union for Cancer Control (UICC). Derajat diferensiasi dibagi menjadi tiga kelompok, yaitu kelompok well differented (diferensiasi baik), moderately differentiated (diferensiasi sedang), dan poorly differentiated (diferensiasi buruk).

Imunoekspresi VDR adalah imunoreaktif sel tumor terhadap pulasan imunohistokimia menggunakan antibodi VDR (VDR (D6): sc13133 dari Santa Cruz, 1:500). Imunoekspresi VDR dinyatakan positif berdasarkan terpulasnya sitoplasma dan membran menjadi berwarna coklat. ${ }^{3}$ Penilaian imunoekspresi VDR dilakukan dengan melihat intensitas dan distribusi pulasan imunohistokimia. Intensitas terdiri atas: negatif (skor 0), lemah (skor 1), sedang (skor 2), dan kuat (skor 3). Penilaian distribusi dilakukan dengan cara membagi satu lapang pandang besar menjadi 4 bidang yang sama besar sehingga satu bidang dinilai sebagai distribusi $25 \%$. Persentasi sel pada keempat bidang 
tersebut kemudian dijumlahkan sehingga didapatkan total ekspresi VDR satu lapang besar. Setelah mendapatkan nilai rata-rata ditentukan tingkat distribusi: ${ }^{11} 0=$ negatif, $1=<10 \%, 2=10$ $50 \%, 3=>50 \%$. Berdasarkan nilai intensitas dan distribusi ekspresi VDR dapat dihitung histoscore (intensitas $\mathrm{x}$ distribusi), yaitu lemah $=1-3$, sedang $=4-6$, dan kuat $=7-9$. $^{3}$

Uji statistik yang bertujuan mengetahui korelasi imunoekspresi VDR dengan stadium dan derajat diferensiasi pada adenokarsinoma kolorektal menggunakan uji statistika korelasi Rank Spearman. Kekuatan korelasi ditentukan berdasarkan Kriteria Guilford (1956), yaitu

$$
\begin{array}{ll}
\geq 0,00 \rightarrow<0,20: & \begin{array}{l}
\text { korelasi yang sangat kecil dan } \\
\text { dapat diabaikan. }
\end{array} \\
\geq 0,20 \rightarrow<0,40: & \text { korelasi yang kecil (tidak erat). } \\
\geq 0,40 \rightarrow<0,70: & \text { korelasi yang sedang. } \\
\geq 0,70 \rightarrow<0,90: & \text { korelasi yang kuat. } \\
\geq 0,90 \rightarrow<1,00: & \text { korelasi yang sangat kuat. }
\end{array}
$$

\section{Hasil}

Tabel 2 menunjukkan bahwa berdasarkan hasil analisis korelasi Spearman diperoleh korelasi antara imunoekspresi VDR dan stadium. Nilai koefisien korelasi (R) diketahui bahwa arah korelasi negatif dengan kekuatan korelasi yang lemah antara imunoekspresi VDR dan stadium. Arah korelasi negatif menunjukkan bahwa variabel stadium dan imunoekspresi memiliki korelasi yang berlawanan arah yang artinya semakin kuat imunoekspresi VDR maka stadium akan semakin rendah. Dengan menggunakan analisis statistik Rank Spearman maka didapatkan nilai $\mathrm{r}$ : -0.341 dan nilai $\mathrm{p}=0.045$ $(\mathrm{p}<0,05)$.

Tabel 3 menunjukkan bahwa data berdasarkan hasil analisis statistika dengan analisis korelasi Spearman diperoleh nilai $p$ $<0,001$ menunjukkan korelasi yang sangat bermakna sehingga dapat disimpulkan terdapat korelasi antara munoekspresi VDR dan derajat diferensiasi. Nilai koefisien korelasi (R) diketahui bahwa arah korelasi positif dengan kekuatan korelasi sedang antara imunoekspresi VDR dan derajat diferensiasi. Arah korelasi positif menunjukkan bahwa imunoekspresi VDR dan derajat diferensiasi memiliki korelasi yang searah yang artinya semakin kuat imunoekspresi VDR maka derajat diferensiasi akan semakin baik. Dengan menggunakan analisis statistik Rank Spearman, didapatkan nilai r: 0.558 nilai $\mathrm{p}=0.000(\mathrm{p}<0,001)$.

\section{Pembahasan}

Pada penelitian ini didapatkan kasus adenokarsinoma kolorektal laki-laki (16

Tabel 1 Karakteristik Subjek Penelitian

\begin{tabular}{lc}
\multicolumn{1}{c}{ Variabel } & Jumlah \\
\hline Jenis kelamin & 16 \\
Laki-Laki & 19 \\
Perempuan & \\
Usia pasien & $53,2857 \pm 12,08444$ \\
Mean \pm SD & 55,0000 \\
Median & 54,00 \\
Range & \\
Derajat diferensiasi histopatologi (grading): & 9 \\
Derajat diferensiasi baik (well differentiated) & 7 \\
Derajat diferensiasi sedang (moderatelly differentiated) & 19 \\
Derajat diferensiasi buruk (poorly differentiated) & 8 \\
Stadium I & 15 \\
II & 12 \\
III & \\
\hline
\end{tabular}


Tabel 2 Korelasi Imunoekspresi VDR (Histoscore) dengan Stadium

\begin{tabular}{|c|c|c|c|c|c|c|}
\hline \multirow{2}{*}{$\begin{array}{c}\text { Imunoekspresi } \\
\text { (Histoscore) }\end{array}$} & \multicolumn{4}{|c|}{ Stadium } & \multirow{2}{*}{ Total } & \multirow{2}{*}{$\begin{array}{c}\text { R } \\
\text { Nilai p }\end{array}$} \\
\hline & & I & II & III & & \\
\hline \multirow[t]{4}{*}{ VDR } & Negatif & 0 & 0 & 0 & 0 & $-0,3410,045^{* *}$ \\
\hline & Lemah & 2 & 4 & 5 & 11 & \\
\hline & Sedang & 2 & 5 & 6 & 13 & \\
\hline & Kuat & 4 & 6 & 1 & 11 & \\
\hline Total & & 8 & 15 & 12 & 35 & \\
\hline
\end{tabular}

Keterangan: korelasi antara ordinal dan numerik menggunakan analisis korelasi Spearman. Nilai kemaknaan berdasarkan nilai $\mathrm{p}<0,05$. Tanda ${ }^{* *}$ menunjukkan signifikan atau bermakna secara statistika. R: koefisien korelasi

kasus) lebih sedikit dibanding dengan kasus adenokarsinoma kolorektal berjenis kelamin perempuan (19 kasus). Keadaan ini ternyata tidak sesuai dengan angka insidens rata-rata karsinoma kolorektal per 100.000 penduduk di Indonesia yang lebih banyak mengenai lakilaki dengan insidens rata-rata sebagai berikut: 19,1 untuk laki-laki dan 15,6 untuk perempuan seperti pada penelitian epidemiologi karsinoma kolorektal di Indonesia. ${ }^{3}$ Menurut Yee dkk. ${ }^{13}$ pada penelitian epidemiologi kanker kolorektal di Asia, dinyatakan bahwa insiden karsinoma kolorektal di Asia pada laki-laki lebih tinggi daripada perempuan.

Pada penelitian ini didapatkan data usia ratarata penderita karsinoma kolorektal dengan median 55 dan range 54,00. Penelitian ini sesuai dengan penelitian yang dilakukan oleh Haggar dan Boushey ${ }^{14}$ yang meninjau insidens, mortalitas, dan survival rate karsinoma kolorektal berdasarkan daerah (regional) mengemukakan bahwa lebih dari 90\% karsinoma kolorektal terjadi pada usia di atas 50 tahun.

Pada penelitian ini terdapat korelasi antara imunoekspresi VDR dan stadium. Hasil nilai koefisien korelasi (R) diketahui bahwa arah korelasi negatif atau mempunyai korelasi yang berlawanan arah yang artinya semakin kuat imunoekspresi VDR maka stadium akan semakin rendah. Hasil penelitian ini sesuai dengan penelitian yang telah dilakukan Shabahang dkk..$^{15}$ yang melaporkan bahwa ekspresi VDR yang paling kuat ditemukan pada adenokarsinoma kolorektal Duke B, ekspresi VDR moderat ditemukan pada Duke C, dan ekspresi VDR yang rendah paling banyak ditemukan pada Duke D. Penelitian oleh Niv dkk. ${ }^{16}$ mengukur kadar vitamin D serum dan dikorelasikan dengan stadium karsinoma kolorektal. Pada penelitian tersebut diperoleh penurunan kadar vitamin D serum pada stadium lanjut, yaitu stadium III dan IV. Agresivitas tumor terjadi disebabkan oleh hilangnya ekspresi VDR. Penurunan ekspresi VDR yang menyebabkan hilangnya kemampuan vitamin D untuk induksi transkripsi gen yang menghasilkan fungsi antiproliferasi sel tumor. Pada karsinoma kolon nonagresif (stadium I dan II) ditemukan peningkatan kadar vitamin D serum yang diperlukan untuk mekanisme inhibisi pertumbuhan sel tumor.

Tabel 3 Korelasi antara Imunoekspresi VDR (Histoscore) dan Derajat Diferensiasi

\begin{tabular}{|c|c|c|c|c|c|c|}
\hline \multirow{2}{*}{$\begin{array}{c}\text { Imunoekspresi } \\
\text { (Histoscore) }\end{array}$} & & \multicolumn{3}{|c|}{ Derajat Diferensiasi } & \multirow{2}{*}{ Total } & \multirow{2}{*}{$\underset{\text { Nilai p }}{\mathbf{R}}$} \\
\hline & & Well & Moderatelly & Poorly & & \\
\hline \multirow[t]{4}{*}{ VDR } & Negatif & 0 & 0 & 0 & 0 & $0,558^{* *} 0,000^{* *}$ \\
\hline & Lemah & 1 & 0 & 10 & 11 & \\
\hline & Sedang & 3 & 3 & 7 & 13 & \\
\hline & Kuat & 5 & 4 & 2 & 11 & \\
\hline Total & & 9 & 7 & 19 & 35 & \\
\hline
\end{tabular}



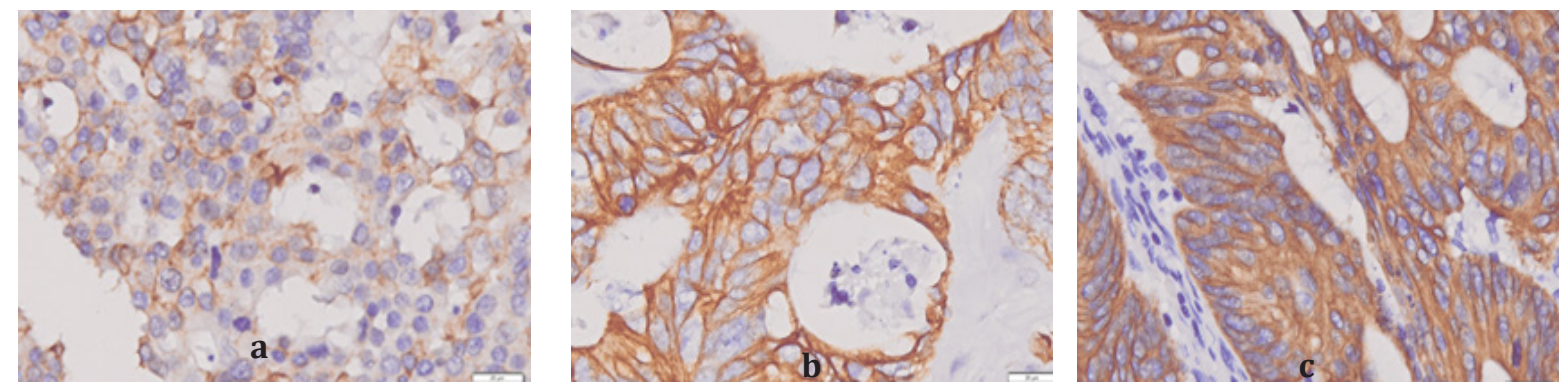

\section{Gambar Pulasan Imunoekspresi VDR Intensitas Kuat. b. Intensitas Sedang. c. Intensitas Lemah (Pembesaran 400x)}

Ekspresi VDR yang paling kuat ditemukan pada stadium yang rendah disebabkan oleh VDR mempunyai aktivitas antiproliferasi sel tumor melalui mekanisme genomik dan nongenomik. Efek genomik VDR berperan langsung terhadap antiproliferasi sel tumor, sedangkan efek nongenomik menghambat proliferasi sel tumor melalui aktivasi second messenger yang dapat melakukan cross-talk dengan efek genomik. ${ }^{17}$ Walaupun VDR bekerja melalui kedua jalur tersebut, mayoritas efek antiproliferasi diperoleh secara langsung melalui efek genomik. ${ }^{18}$

Melalui jalur genomik di inti sel, VDR berperan sebagai antiproliferasi melalui ikatan antara calcitriol dan reseptornya (VDR) membentuk heterodimer dengan retinoic $X$ receptor (RXR) dan juga dengan ligannya (9 cis-retinoic acid). Dimer tersebut membentuk kompleks dengan vitamin $D$ response elements (VDREs) yang berhubungan dengan transkripsi gen untuk menghasilkan fungsi antiproliferasi. ${ }^{7}$ Reseptor vitamin $\mathrm{D}$ mempunyai jalur nongenomik yang berada di sitoplasma, dengan mekanisme rapid action VDR mengikat calcitriol pada membran VDR di caveolae membran plasma. Ikatan VDRcalcitriol pada membran plasma mengaktivasi beberapa second messenger system seperti phospholipase $\mathrm{C}, \mathrm{G}$ protein coupled receptors, dan phosphatidylinositol-3-kinase (PI3K).

Pada penelitian ini menunjukkan terdapat hubungan antara imunoekpresi VDR dan derajat diferensiasi pada adenokarsinoma kolorektal. Hasil tersebut sesuai dengan penelitian yang dilakukan oleh Gocek dan Studzinski ${ }^{19}$ yang melaporkan bahwa level VDR mulai meningkat pada awal karsinogenesis atau meningkat pada mukosa kolon manusia selama perkembangan awal tumor, tetapi kadarnya menjadi rendah pada poorly differentiated dan stadium lanjut. Hal tersebut membuktikan bahwa VDR mempunyai efek menahan pertumbuhan sel tumor.

Pada penelitian ini diperoleh hasil bahwa overekspresi VDR lebih sedikit pada high grade tumor dibanding dengan low grade tumor.

Hasil penelitian ini sudah membuktikan peran VDR dalam perkembangan patogenesis adenokarsinoma kolorektal sehingga vitamin D dan analog sintetisnya dapat digunakan sebagai terapi adjuvan pada pasien kanker kolorektal dengan ekspresi VDR yang positif. ${ }^{18}$ Data epidemiologi juga mendukung peran vitamin D dalam mencegah progresi neoplastik pada epitel kolon. Penelitian oleh Shabahang dkk. ${ }^{15}$ membuktikan bahwa hilangnya ekspresi VDR merupakan salah satu faktor meningkatnya progresi ke arah keganasan. Penelitian tersebut memungkinkan penggunaan vitamin D dan VDR sebagai chemoprevention karsinoma kolorektal.

Penelitian reseptor vitamin D dan calcitriol telah dilakukan pada model xenograf memakai galur sel tumor karsinoma kolon, payudara, prostat, retinoblastoma, dan juga osteosarkoma. ${ }^{20}$ Pada penelitian ini mempergunakan analisis imunohistokimia pada jaringan tumor pasien. Imunoekspresi VDR yang meningkat pada adenokarsinoma kolorektal yang merupakan indikator prognosis yang baik karena VDR yang berikatan dengan calcitriol akan meningkatkan jumlah ocludin, zonula occludens (ZO)-1, -2, dan claudin-2, -12, yaitu suatu komponen pada tight junctions yang berlokasi predominan pada membran plasma. ${ }^{10,20}$ Selain itu, VDR dan calcitriol dapat meningkatkan relokalisasi vinculin pada struktur intercelular junction. Data tersebut membuktikan bahwa VDR menginduksi ekspresi protein adhesi interseluler yang penting untuk terbentuknya diferensiasi yang baik dari suatu tumor. ${ }^{20}$

Vuolo dkk. ${ }^{17}$ telah menyatakan kadar vitamin D yang rendah berhubungan dengan peningkatan mortalitas dan agresivitas kanker kolorektal, serta ditemukan penurunan sebanyak 30\% formasi adenoma kolorektal pada pasien dengan kadar calcitriol yang tinggi dibanding dengan 
pasien yang memiliki kadar calcitriol yang rendah. Angka kesintasan hidup pada penelitian prospective cohort terhadap 1.295 pasien kanker payudara postmenopause dihubungkan dengan kadar serum calcitriol. Hasil penelitian ini menunjukkan bahwa kadar Calcitriol serum yang rendah berhubungan dengan angka kesintasan hidup yang rendah. ${ }^{17}$

Simpulan, penelitian ini telah menunjukkan peranan penting VDR dalam mempertahankan stadium awal dan diferensiasi tumor dibuktikan dengan jumlah reseptor vitamin D lebih tinggi pada stadium awal dan pada kelompok well differentiated dibanding dengan stadium tinggi dan juga kelompok poorly differentiated. Hasil penelitian ini dapat digunakan sebagai acuan dalam mempertimbangkan pemberian terapi calcitriol sebagai terapi target pada pasien adenokarsinoma kolorektal stadium awal dan diharapkan pemberian calcitriol in ini dapat menurunkan morbiditas dan juga meningkatkan prognosis.

\section{Daftar Pustaka}

1. Center MM, Jemal A, Smith RA, Ward E. Worldwide variations in colorectal cancer. CA Cancer J Clinicians. 2009;59(6):366-78.

2. Sudoyo A, Hernowo BS, Krisnuhoni E, Reksodiputro AH, Hardjodisastro D, Sinuraya ES. Colorectal cancer among young native Indonesians: a clinicopathological and molecular assessment on microsatellite instability. Med J Indonesia. 2010;19(4):24557.

3. Erida Y, Aminah $\mathrm{H}$, Yulianti $\mathrm{H}$, Hernowo BS. Vitamin D receptor (VDR) and phosphatidylinositol 3-kinase (PI3K) independently affected colorectal adenocarcinoma differentiation. Indonesian J Clin Pharm. 2015;4(4):264-74.

4. Derwinger K, Kodeda K, Bexe-Lindskog E, Taflin H. Tumour differentiation grade is associated with TNM staging and the risk of node metastasis in colorectal cancer. Acta Oncologica. 2010;49:57-62.

5. Pereira F, Larriba MJ, Munoz A. Vitamin D and colon cancer. Endocrine-related Cancer. 2012;19(3):51-71.

6. De Hertogh G, Geboes KP. Practical and molecular evaluation of colorectal cancer: new roles for the pathologist in the era of targeted therapy. Arch Pathol Lab Med. 2010;134(6):853-63.

7. Kristin Deeb DT, Candace Johnson. Vitamin
D signalling pathways in cancer: potential for anticancer therapeutics. Nat Rev Cancer. 2007;7(9):684-700.

8. Ma Y, Trump DL, Johnson CS. Vitamin D in combination cancer treatment. J Cancer. 2010;1:101-7.

9. Garland CF, Garland FC, Gorham ED, Lipkin M, Newmark H, Mohr SB, dkk. The role of vitamin $\mathrm{D}$ in cancer prevention. Am J Public Health. 2006;96(2):252-61.

10. Samuel S, Sitrin MD. Vitamin D's role in cell proliferation and differentiation. Nutrit Rev. 2008;66:116-24.

11. Laang Kvq, Nguyan LTH. Vitamin D and cancer, advances in cancer management: InTech; 2012 [diunduh 17 Mei 2013]. Tersedia dari: www.intechopen.com/books/advances-incancer-management/vitamin-d-cancer.

12. Puppa G, Sonzogni A, Colombari R, Pelosi G. TNM staging system of colorectal carcinoma a critical appraisal of challenging issues. Arch Pathol Lab Med. 2010;34:837-56.

13. Yee Y, Tan V, Chan P, Hung I, Pang R, Wong B. Epidemiology of colorectal cancer in Asia. J Gastroenterol Hepatol. 2009;24(12):1810-6.

14. Haggar FA, Boushey RP. Colorectal cancer epidemiology: incidence, mortality, survival, and risk factors. Clin Colon Rectal Surg. 2009;22(4):191-7.

15. Shabahang $M$, Buras RR, Davoodi F. 1,25-dihydroxyvitamin D3 receptor as a marker of human colon carcinoma cellline differentiation and growth inhibition. Cancer Research. 1993;53:3712-8.

16. Niv Y, Sperber AD, Figer A. In colorectal carcinoma patients, serum vitamin D levels vary according to stage of the carcinoma. Cancer. 1999;86(3):391-7.

17. Vuolo L, DiSomma C, Faggiano A, Colao A. Vitamin D and cancer. Frontiers Endocrinol. 2012;3:1-11.

18. Evans SR, Nolla J, Hanfelt J. Vitamin D receptor expression as a predictive marker of biologicalbehavior in human colorectal cancer'. Clin Cancer Research. 1998;4:15915.

19. Gocek E, Studzinski GP. Vitamin D and differentiation in cancer. Crit Rev Clin Lab Sci. 2009;46(4):190:1-31.

20. Pálmer HG, González-Sancho JM, Espada J, Berciano MT, Puig I, Oz AM. Vitamin D3 promotes the differentiation of coloncarcinoma cells by the induction of E-cadherin and theinhibition of beta-catenin signaling. J Cell Biol. 2001;154(2):369-87. 